\title{
JUSTIÇA E ÉTICA COMO FUNDAMENTOS DO DIREITO NA FILOSOFIA ANTIGA
}

\author{
JUSTICE AND ETHICS FROM THE ANCIENT PHILOSOPHY
}

\author{
Gerson Pereira Filho* \\ Isadora Prévide Bernardo**
}

\section{RESUMO}

O artigo propõe uma apresentação dos conceitos de Justiça e Ética a partir da filosofia de Sócrates e Platão, no contexto grego, assim como nos remete ao pensamento e obra de Cícero, no contexto romano, para nos permitir pensar as bases da filosofia do direito. Ao se considerar a relação entre o jusnaturalismo e a filosofia da natureza entre os gregos antigos, e a passagem para a antropologia socrático-platônica, posteriormente consolidada em seus aspectos jurídicos por Cícero e sua base estóica, pretende-se pensar a questão das constituições legislativas, formas de governo, princípios e fins das leis na perspectiva humanista que tais pensadores clássicos sugeriram, na contramão do tecnicismo jurídico contemporâneo. Em Sócrates como uma "filosofia do agir", em Platão como uma possibilidade efetiva para o ordenamento da pólis, em Cícero como princípio para a vida pública, encontramos fundamentações que muito podem oferecer para a filosofia do direito na atualidade. PALAVRAS-CHAVE: Justiça. Ética. Direito. Filosofia Grega. Filosofia Latina.

\section{ABSTRACT}

The article aims a presentation of the concepts of Justice and Ethics from the philosophy of Socrates and Plato in the Greek context, as well as referring to the thought and work of Cicero, in the Roman context; this allow us to think the bases of the philosophy of law. Considering the relation between jusnaturality and natural philosophy among the ancient Greeks, and the transition of Socratic-Platonic anthropology to Cicero, later consolidated in its juridical aspects and in a stoic base, we intend to think about the question of legislative constitutions, forms of government, principles and ends of laws in the humanistic perspective that such classical thinkers have suggested, contrary to contemporary legal technicality. In Socrates as a "philosophy of action", in Plato as an effective possibility for the ordering the polis, in Cicero as a principle for public life, we find foundations that can offer much for the philosophy of law nowadays.

KEY-WORDS: Justice. Ethic. Right. Greek Philosophy. Latin Philosophy.

\footnotetext{
* Mestre (1999) e Doutor (2005) em Filosofia pela Universidade Estadual de Campinas-Unicamp. Pós-doutor pela UNICAMP. Professor Adjunto III da Pontifícia Universidade Católica de Minas Gerais. E-mail: gerson@pucpcaldas.br.

** Mestrado em Filosofia pela USP (2013) e doutoranda pela USP. Docente na especialização lato sensu de filosofia, PUC Minas. E-mail: isaprevide@ hotmail.com.
} 


\section{INTRODUÇÃO}

Em seu sentido estrito, a Filosofia do Direito está situada no campo das ciências jurídicas, voltada especialmente para as investigações sobre teorias e métodos que possam ser aplicados às relações e instituições nesse campo, muitas vezes como aporte teórico para abordagens técnicas e pragmáticas.

Entretanto, cabe ressaltar que a consolidação das ciências jurídicas e do Direito estão intrinsicamente vinculadas ao desenvolvimento histórico do pensamento filosófico desde seus primórdios e de forma indissociável das concepções de ética e justiça inseridas nas especulações e práxis dos antigos, desde as indagações cosmológicas e da physis (natureza), ou mesmo antes, nas narrativas míticas, transitando para as questões ontológicas, epistemológicas, antropológicas, políticas, psicológicas e sociais que se desenvolveram com o avançar da Filosofia. Assim, conceitos e temas que se tornaram objetos do Direito são derivações interdisciplinares das elaborações filosóficas.

Podemos nos remeter à formação do pensamento jurídico moderno e percebermos tal relação entre a Filosofia e o Direito de forma clara, como no humanismo da Renascença (Maquiavel, Jean Bodin, Hugo Grócio, Thomas More, a título de exemplos), ou nas concepções racionalistas e empiristas que se seguiram (Descartes, Hobbes, Spinoza, Locke, Vico), no decorrer dos séculos XVI ao XVII. O período histórico-filosófico posterior, a chamada "filosofia das luzes", ou seja, o "iluminismo" que se praticou entre os séculos XVIII e XIX, permitiu, a partir da Filosofia, a fundamentação dos pressupostos teóricos que deram sustentação às ciências jurídicas, sobretudo com filósofos como Rousseau, Montesquieu, Kant e tantos outros. O "cientificismo" e o "positivismo" jurídico que se proclamaram a partir do século XIX e XX como pilares do Direito, não escaparam das bases filosóficas apresentadas pelas diferentes linhas do pensamento contemporâneo. Pensar na Filosofia do Direito é, portanto, ir além dos procedimentos técnicos e metodológicos das ciências jurídicas, para adentrar o universo subjetivo da ética e da justiça. Como nos diz um dos autores da área:

\footnotetext{
A filosofia, ao mesmo tempo em que é uma sistematização do pensamento, é um enfrentamento do próprio pensamento e do mundo. Tudo isso pode se aplicar a objetos específicos da própria filosofia, como o direito. E, assim sendo, a filosofia do direito nada mais é que a filosofia geral com um tema específico de análise, o direito. (MASCARO, 2016 p. 10).
} 
Nesse sentido, os autores deste artigo se propõem a revisitar os fundamentos básicos da antiguidade filosófica que ainda hoje refletem nas complexas abordagens que envolvem as ciências jurídicas e a Filosofia do Direito em particular, pois "delimitar aspectos relacionados à Filosofia do Direito na antiguidade é pensar sobre o conceito de justiça e seus desdobramentos em relação à conduta humana, à ética, à política, à educação e ao ordenamento da vida social” (PEREIRA FILHO, 2015, p. 31).

\section{CONCEPÇÕES DE JUSTIÇA NA FILOSOFIA GREGA ANTIGA}

Em sua origem etimológica, a expressão "justiça” em português, é derivada diretamente do latim "justitia", que representava, entre os romanos, a divindade que veio a simbolizar o Direito, ou seja, a deusa com vendas nos olhos com a função de assegurar o equilíbrio e a imparcialidade nos juízos deferidos. Daí o sentido do direito associado à justiça enquanto mediador das ações humanas perante a vida coletiva e, no caso da antiguidade, perante os deuses, responsável por assegurar a aplicação do juízo e da correção.

Entre os gregos, tal divindade era a Diké (que mantinha os olhos abertos e não vendados) para julgar com claridade, o mais próximo da verdade. De Diké, temos “dikaiosyne” como a prática da justiça. Segundo Nicola Abbagnano (2000, p. 593), em seu dicionário filosófico, por justiça, em seu significado original, devemos compreender como sendo "a ordem das relações humanas ou a conduta de quem se ajusta a essa ordem”. Concluímos dessa definição que a ideia de justiça voltada para o comportamento humano e social está vinculada à ideia matemática, geométrica, de proporcionalidade, retidão, ordenamento. É justo aquilo que é "orthós” (reto, direito, em grego) ou “directus" (no latim).

Em sentido amplificado, é possível identificar ao menos três conotações da ideia de justiça nos primeiros gregos. Primeiramente, no sentido colocado acima, a justiça personificada numa divindade (Diké) expressa o pensamento de que é justo aquilo que está em acordo com a vontade, sabedoria, intenção e perfeição dos deuses que devem guiar as ações humanas; uma visão determinista, que acaba por se associar também ao conceito de destino (moira), dentre os gregos, dramaticamente traçado e previsto pelos deuses a seu critério. Num segundo sentido, a justiça grega está identificada à ordem natural do universo; à harmonia estabelecida pela natureza (physis), de modo a garantir o equilíbrio natural. Temos aí as bases do jusnaturalismo. Num terceiro caso, encontramos a concepção de justiça como o 
modo de ordenar a vida humana na relação social, na pólis (cidades-estados), a partir da convivência em conformidade com normas, valores, tradições e leis coletivas.

É possível verificar um movimento conceitual e teórico entre tais concepções pela leitura das obras produzidas entre os autores gregos que transitam do mítico e poético, à dramaturgia, filosofia e narrativas históricas e político-discursivas. Percebemos esta passagem, não mecânica ou linear, mas dinâmica e inter-relacionada, do mytho (mito) à physis (estudos da natureza) e daí para a filosofia política e ética, centrada nas ações humanas em seus aspectos antropológicos, psicológicos e sociais. Há um movimento que perpassa do mundo dos deuses ao mundo cósmico e natural e ao mundo humano e da cidade/sociedade humana, do mytho à physis, à pólis e ao ântrophos.

São conhecidas as narrativas teogônicas em Hesíodo (750/650 a.C.) ou a literatura épica-homérica (séc.VIII a.C.), que demonstram a passagem do caos (desordenamento) para o cosmo (ordenamento) do universo, da natureza e de tudo que há, pela intervenção das divindades. A dramaturgia grega, especialmente as Tragédias (Ésquilo, Sófocles, Eurípedes, dentre outros), traz em suas obras os dramas vividos pelos personagens diante da justiça divina, do controle das Moiras, que são as musas divinas que tecem o destino humano, à percepção da culpa e de um esboço de consciência ética e moral que persegue a mente desses personagens, diante das ações pessoais e coletivas. É o drama vivido por Édipo Rei, Jocasta e Antígona, dentre tantos outros, diante do peso das ações moralmente avaliadas por si próprios, pela sociedade, pelo destino natural e, no caso, pelas divindades. Inevitável esse enfrentamento entre o que é o justo e o injusto, o certo e o errado, o falso e o verdadeiro.

Nos primeiros filósofos, chamados de "físicos" ou da "physis", como encontramos nos fragmentos deles próprios ou nas abordagens dos diálogos platônicos, ensaios aristotélicos ou descrições historiográficas antigas, temos a transição dessa "ordem" ou "justiça divina” para uma justiça natural ou cosmológica.

A busca do princípio universal que explicasse a realidade de cada coisa (ser), entendida como a busca pela "arché" (princípio natural das coisas) conduziu também, inevitavelmente, à busca pelas “causas” - princípio da causalidade, (aítia, em grego) capaz de justificar os "porquês" dos fenômenos naturais e do agir humano. Como regra comum, tais "porquês" teriam uma causalidade lógica, fundamentada em princípios ou leis naturais, para assegurar a harmonia e a ordem cósmica. O movimento (kynésis) de tudo estaria associado aos princípios da physis, enquanto ordem natural. Ordenamento este que valia tanto para a 
natureza quanto para a cidade e os seres humanos; a imagem do "macrocosmo" (universo natural) que se reflete no "microcosmo" (a cidade, o ser humano). Tales, Heráclito, Pitágoras, Demócrito e toda a lista dos chamados "primeiros filósofos" gregos, de certo modo se aliam a essa linha comum de pensamento que Platão (Fédon, 96a) chamou de "exame da natureza", de modo a se buscar nas leis naturais a razão explicativa para os acontecimentos na cidade e na vida humana.

A ordem natural seria necessariamente justa, reta/correta, equilibrada, harmônica. Seria inconcebível um universo desordenado, aleatório; embora muitos desses filósofos tenham identificado e buscado compreender aqueles fenômenos que muitas vezes geram o caos e o desequilíbrio. O próprio desajuste ou desequilíbrio que se manifesta muitas vezes na natureza teria uma causa explicativa em harmonia com o ordenamento cósmico geral.

Assim, à justiça humana caberia se espelhar nessa justiça natural, representada principalmente nos seguintes princípios:

I- Equilíbrio nas ações (sophrosýne);

II- Justa medida (méden ágan);

III- Virtude (areté);

IV- O belo (kalós) e o bom (agathós).

Tais princípios seriam capazes de evitar que o ser humano se desviasse diante daquilo que seria injusto, fruto da desmedida, do desregramento, da desordem, da discórdia, ou seja da hýbris, ou de tudo aquilo que foge da lei natural que é, "por natureza" harmônica e correta. Temos aí, em linhas gerais, as bases do jusnaturalismo ou Direito Natural. Os primeiros legisladores ou juristas gregos, de certo modo, se guiaram por tais fundamentos, como Drácon, Sólon, Clístenis ou mesmo muitos dos filósofos que foram, também, legisladores, contribuindo para elaborar as constituições de sua cidade-estado, como podemos observar no fragmento de Estobeu IV.1.43, do filósofo Demócrito, de Abdera (460/370 a.C.), pai da filosofia atomista e um dos primeiros materialistas:

É preciso julgar de maior importância que tudo o mais, os interesses da cidade, para que sejam bem dirigidos sem armar contendas contrárias ao direito e sem assumir para si um poder contrário ao bem comum. Uma cidade bem dirigida é o maior apoio e tudo nela está contido: salva a cidade, tudo está salvo; destruída a cidade, tudo está destruído [...] A lei quer beneficiar a vida dos homens, mas ela pode fazêlo quando eles querem receber o benefício, pois indica para os que o querem a virtude que lhes é própria. (SOUZA, 1985, p.343). 


\subsection{SÓCRATES: SABEDORIA E PRÁTICA NO AGIR HUMANO}

Na quase totalidade dos diálogos platônicos que temos Sócrates como personagem central, os debates maiêuticos ocorrem em torno de temas éticos, na busca daquilo que justificaria a conduta humana da virtude e da prática virtuosa dos interesses da pessoa (cidadão), diante da cidade (bem comum). Tais embates ocorrem, como se sabe pela história da filosofia, sobretudo em oposição a certa parcela de sofistas, pensadores e instrutores gregos, que nem sempre se pautavam pela ética em seus ensinos, mais preocupados que estavam com a formação retórica e as habilidades para o sucesso na vida pública. É sabido, pelos estudos mais aprofundados da filosofia, que nem toda prática sofística se enquadra nessa definição, muitas vezes preconceituosa. De qualquer modo, nesses "diálogos socráticos" escritos por Platão, se construiu um conjunto de fundamentos para a ética, a política e a filosofia do direito.

Aqui tomamos como referência, dois desses diálogos escritos por Platão, que dá voz ativa a Sócrates (que nada escreveu, até onde se sabe): Críton, também chamado "Do dever" e o conhecido diálogo A República (Politeía), cujo cognome que aparece em algumas edições antigas é, exatamente, "Da justiça".

Não pretendemos, obviamente, neste curto artigo, nos determos numa exegese ou hermenêutica de tais obras, que tem ocupado estudos completos das múltiplas questões que apresentam e possibilitam, no campo filosófico e noutras áreas. Apenas queremos ressaltar, a partir desses diálogos, sinteticamente, alguns princípios que consideramos ali presentes para nortear o que seja a justiça e o cumprimento justo do dever e do direito.

Em síntese, podemos, portanto, extrair desses diálogos que a cidade deve ser ordenada por leis justas e que tal justiça da cidade somente é possível se for habitada por cidadãos justos. Cidadãos justos é que tornam a cidade justa. Para se ter cidadãos justos, há que se ter uma educação justa, desde o âmbito familiar ao convívio social e institucional, pautada, em especial, por uma educação filosófica, que é aquela capaz de ensinar o correto e sábio uso da razão para o discernimento das ações. A educação filosófica permite se chegar ao conhecimento do bem e da(s) virtude(s) que deve(m) ser praticada(s) na cidade para que se atinja a justiça. $\mathrm{O}$ cidadão justo deve ser fiel às leis da cidade, e acreditar que tais leis visam 
aos bem comum, se construídas pelos princípios da sabedoria e da razão. A justiça deve sempre ser pratica pelos que governam e pelos cidadãos; até mesmo a injustiça deve ser paga com justiça. Não se pratica a justiça com palavras demagógicas e enganosas (como alguns sofistas e políticos), mas com ações virtuosas. Esta deve ser a missão do filósofo e daqueles que são instruídos pela filosofia.

A lição socrática desafia a todos os cidadãos que se pretendem justos a ir para além das palavras em busca do real significado das virtudes, pela prática da verdade (alétheia), com base no conhecimento (epistéme) do bem (kalá). O conhecimento da verdade deve ser a meta não só do filósofo, mas de todo cidadão e do governante, pois somente assim a cidade atingirá um convívio que assegure o bem comum. Este conhecimento é viável pelo exercício continuado da razão, em acordo com o pensamento filosófico (logos), o que permite atingir os conceitos e ideias plenas a respeito das virtudes que se deve praticar. Daí, como se sabe na tradição filosófica, dessas argumentações se passou a constituir as especulações metafísicas e ontológicas a respeito do tal "mundo das ideias" ou das "formas", em que o alvo supremo, ao menos em A República, seria atingir a ideia do bem, representada pela simbologia do sol, numa analogia cosmológica, como o astro que tudo esclarece e tudo permite ver e compreender com clareza. Agir para o bem, seria encontrar o bem, e assim, atingir a justiça e demais virtudes.

O caminho para isso seria a paidéia, a educação integral, teórica e prática, desde a infância, até a idade da plena razão. O lógos (razão) corretamente (justamente) educado, permite o acesso à verdade e sua apreensão. Uma vez apreendida a verdade, é possível agir justamente nas relações pessoais e para o bem da coletividade (pólis).

A apreensão do conhecimento verdadeiro permite o discernimento do que é o certo e do que é o errado, também do ponto de vista ético e moral, e não apenas no campo epistemológico. O conhecimento passa a ter com Sócrates, um sentido ético: indicar o caminho do bem! Somente podem ser considerados como "educação", os ensinamentos dela decorrentes que se propuserem a ensinar a virtude (areté). O conhecimento é a fonte para a educação, porém este ato de educar dever ter por finalidade conhecer a virtude que permita a prática do bem e da justiça, e somente assim se pode almejar a felicidade (eudaimonia) pessoal e para a cidade.

Em resumo, a justiça é o caminho do bem e da felicidade; para se chegar a tal estado, cabe se dedicar à busca da sabedoria (sophia), em sua forma racional, a Filosofia, que vem a 
ser o princípio do Direito (do que é reto). O discernimento (diákrysis) entre o bem e o mal, o certo e o errado, é que permite a realização da existência da pessoa em sua coletividade (o ethos), medida por sua conduta, qual seja, a medida ética. Inúmeras são as condutas virtuosas - coragem, temperança, prudência, amizade, paz, e muito mais que são agrupadas para constituir a unidade da virtude plena em sua forma máxima (eidos), imagem da justiça e do bem.

\subsection{PLATÃO: DA JUSTIÇA IDEAL À JUSTIÇA POSSÍVEL}

Diferente da interpretação de muitos, a filosofia platônica não é uma simples extensão da filosofia socrática. Nem tampouco se pode entender a filosofia socrática como uma invenção platônica. Se temos em Platão o maior porta-voz dos ensinamentos de Socrátes, o estudo apurado da obra platônica permite compreender os pontos que distinguem ou aproximam os dois filósofos e as vertentes que deles decorreram. Não pretendemos aqui avançar nessa questão. Ressaltamos apenas que além das questões conceituais que aproximam ou distanciam o mestre e o discípulo, cabe destacar em Platão o aprofundamento epistemológico e metodológico das questões levantadas e, apesar das dificuldades encontradas devido a seu método nada sistemático, a começar pela forma de seus textos - diálogos cênicos - pouco conclusivos e nada dogmáticos, o que só faz aumentar sua complexidade, diversidade hermenêutica e possibilidades teóricas.

Desse modo, o que apontamos neste tópico sobre a filosofia da justiça ou do direito em Platão, nada mais são do que modestas reflexões a esse respeito.

Como Platão não nos ofereceu, provavelmente por opção, uma sistematização epistemológica, não é tarefa simples apresentar claramente seus conceitos e métodos. De modo simplório, podemos dizer que encontramos em Platão (neste ponto em concordância com o mestre Sócrates) uma relação direta entre ética e conhecimento. O conhecimento adquirido cotidianamente e que faz parte da vida da maioria das pessoas em suas decisões e ações é aquele do senso comum, da doxa (opinião), numa modalidade não plenamente racional, e que deve ser aprimorada pela educação da razão para que seja possível atingir o grau noético (nous = estágio maior da razão), e assim a apreensão dos conceitos e ideias em sua forma pura. Portanto, a ética é decorrente de um processo intelectivo. Quanto mais primorosa a formação do intelecto, mais próximo se está do alcance ético. O saber ético é 
decorrente do saber técnico (saber fazer) e do saber dialético (Filosofia). A ética portanto adquire um status científico - a ciência do bem e do justo - como também as ações políticas na cidade; é o que encontramos, dentre outras obras, no diálogo $O$ político. Política e Ética estão entrelaçadas e são, ao mesmo tempo, arte e técnica (teckné), filosofia e ciência, conceito e práxis.

No entanto, nos diálogos encontramos também um caráter psicológico e não somente epistemológico na concepção de ciência, sobretudo quando se refere à ciência do bem e do justo, ou seja, a ética. Esta está diretamente relacionada à alma (psiquê), à mente, aos sentimentos e emoções humanas. Nesse sentido, também contrariando algumas linhas de interpretação, não é correto reduzir a filosofia ética de Platão a um intelectualismo puro e simples; trata-se, sem dúvida, de uma ética "emotivista", em grande parte movida pela vontade, pelo desejo, ainda que essas emoções devam estar em sintonia com a razão, como encontramos no famoso mito ou alegoria do "cavalo alado", no diálogo Fedro, em que dois cavalos, um representando a razão e o outro a paixão, são guiados por um cocheiro que tem a difícil tarefa de preservar o equilíbrio entre essas distintas naturezas, e assim evitar uma disputa que possa conduzir à autodestruição. Preservar esse equilíbrio é fundamental no plano da alma/psiquê individual, e fundamental para se preservar também a "alma" da cidade (diálogo A República) e a "alma" do Mundo (diálogo Timeu). A ética é, então, uma psicologia. Dessa psicologia ética platônica é possível esboçar um modelo do qual fazem parte a contemplação do bem e do justo; a reflexão sobre o melhor agir para se alcançar o bem e o justo; a deliberação, como fruto da razão, para se escolher o bem e o justo. Esse processo é um exercício filosófico, teorético (por visar o conhecimento do conceito em sua natureza mesma) e dialético (por ter que lidar com a contradição inerente a todo pensamento e ação). $\mathrm{O}$ exercício teorético e dialético é construído tanto do ponto de vista intelectivo e pelo esforço racional de compreender e discernir, quanto pela vivência prática nas relações da cidade e do convívio, que revelam o que é ou não o bem e o justo, pois,

Desse raciocínio ocorre uma transposição da ética, da epistemologia e da psicologia para a ontologia. A harmonia, a ordem, o equilíbrio, a medida certa, a proporção justa, assim como no mundo físico, nas relações matemáticas, na geometria, na harmonia musical, é praticável no mundo das relações políticas e sociais, desde que sejam assimiladas e apreendidas pela razão, no exercício dialético do pensamento que visa atingir as formas ideais. (PEREIRA FILHO, 2015, p. 55). 
Decorrente do movimento dialético presente no próprio conjunto textual dos diálogos platônicos, constatamos que há uma passagem da idealização conceitual do que seja o bem, o justo, as virtudes em si, para o reconhecimento de que é pela práxis dos cidadãos e dos governantes na cidade que se pode encontrar o melhor indício do que contribui para o bem coletivo e individual e do que contribui para a decadência ética (infelizmente, em geral predominante). Assim, há que se buscar os meios para "curar" esse mal que afeta as cidades, um "fármaco" eficaz que possa apresentar esperanças de revitalização ética e política, para o bem de todos. Salvar a cidade de seus males! Eis a missão principal do filósofo, do governante, do cidadão. E qual será esse fármaco? Muitas podem ser as alternativas a serem buscadas, mas uma delas será moldada ao longo de vários diálogos, para se consolidar no último deles, As Leis.

A salvação ou "cura" ética para a cidade está na capacidade racional de se constituir leis justas, boas, eficazes, com função educativa, que ensinem aos cidadãos e governantes como agir pelo bem e pela justiça. Aí se denota o vínculo mais forte em Platão entre suas concepções de ética e justiça com o que veio a se constituir modernamente o campo do Direito. Platão nos apresenta assim uma filosofia do Direito muito bem elaborada em sua obra e particularmente nesta última. A grosso modo, podemos apontar alguns elementos dessa filosofia do direito em Platão, como por exemplo, a preocupação em avaliar a possibilidade de universalizar valores e práticas sem penalizar as diversidades locais; a investigação sobre a possibilidade racional de se atingir conceitualmente o conhecimento do bem, do justo, do verdadeiro; como encontrar métodos eficazes para a educação do homem e da cidade na prática da justiça e do bem; como enfrentar as contradições da vida política e social diante da necessidade da harmonia (?); como descobrir o real significado de cada uma das virtudes e praticá-las; como passar de um Estado idealizado com base nos princípios bons e justos, como a "cidade ideal" que temos em A República, para uma cidade real, norteada por tais princípios ou o mais próxima deles, como encontramos em As Leis; como, ao se pensar a ética e a justiça é indispensável que se pense a política, a melhor forma de governo, a melhor legislação, que permitam a prática efetiva do que propõe a filosofia. Na verdade, no espírito aberto, dialético e indagador dos diálogos platônicos, nenhum desses pontos pode ser tomado como resposta afirmativa, mas como possibilidade. Com suas diferentes nuances, pode-se provisoriamente concluir que 
a filosofia do agir socrático está focada na reflexão que busca orientar a melhor conduta humana mediante o aprendizado das ações virtuosas, consequentemente sugerindo o afastamento dos males e desregramentos. Platão avança no sentido de compreender os fundamentos e possibilidades da prática virtuosa a partir das investigações que pretendem atingir a natureza última do que são tais ações humanas, do que é o próprio ser humano, do que é a cidade, contribuindo, no caso específico do Direito, para a formulação dos conceitos e concepções que regem as relações e instituições jurídicas, éticas, morais e políticas na tradição helênica e que se aplica à formação do mundo ocidental (PEREIRA FILHO, 2015, p.56).

Com a palavra, e finalizando esta parte, o próprio Platão, na abertura do diálogo $A s$ Leis (624 a), ao dar voz ao anônimo personagem, Ateniense: "será a um deus ou a homens a quem remontaremos com ânimo até às origens da organização das vossas leis?" (DIÈS,A, 1956, p. 15, tradução nossa).

Embora a resposta imediata a essa pergunta inicial do diálogo remeta à responsabilidade de legislar sobre a cidade e os seres humanos, aos deuses, veremos, no decorrer do diálogo, que não é bem assim; se nas legislações mais antigas dos próprios gregos, assim fora, a partir da possibilidade de racionalização filosófica, dentro da capacidade e liberdade humanas, cabe aos mesmos a responsabilidade de encontrarem opções legislativas que possam ser aplicadas à cidade e às pessoas em suas trajetórias ética e política, pautadas pelo bem e pela justiça.

\section{A TRANSIÇÃO HELENÍSTICA: DOS GREGOS A CÍCERO}

Quando Cícero se refere à guerra contra Cartago, isso quer dizer as guerras púnicas, que ocorreram de 264 a.C a 146 a.C. Essa guerra introduziu no "agreste Lácio" contribuições ao pensamento romano no período helenístico ${ }^{1}$. Segundo Momiglian (1990, p. 21-22)o:

\footnotetext{
${ }^{1}$ O período helenístico compreendeu de 323 a.C. - ano da morte de Alexandre - até 31 a.C., quando findou a república romana, e Augusto em 27 a.C. assumiu o poder dando início ao período Imperial (TARN, 1982). Neste período, em um vasto território, com o centro cultural em Alexandria, desenvolveram-se o ceticismo, o epicurismo e o estoicismo, e havia grande circulação das artes helênicas e orientais. Além disso, havia uma língua para expressar o diálogo entre esses povos, ou, melhor, um só povo, era a koiné. Politicamente, destacaria, de acordo com Oliva Neto (1993), que a vitória de Alexandre trouxe consequências, a saber, o fim da pólis, instância com a qual o homem grego se relacionava, antes de participar de um mundo com uma concepção universalista. Os cidadãos gregos participavam da vida política de modo muito particular e específico. Esse modo de se relacionar com a cidade foi substituído pela universalidade do ecúmeno e pela universalidade que a língua comum, a koiné, proporcionava. Então, o sentido de pátria tornava-se universal e, de acordo com o pensamento estoico, pensava-se em uma cosmopolis, ligada à ideia da onipresença de uma razão universal. Assim, não há mais espaço para um mundo particular, pois há uma outra concepção espacial e geográfica, logo, Roma não é apenas a urbe, mas todo um grande território.
} 
O período decisivo da assimilação da cultura grega em Roma é o das primeiras guerras púnicas. Enquanto lutavam contra Cartago, os romanos aprenderam grego e incorporaram costumes e conhecimentos gregos com rapidez crescente. Não houve crescimento correspondente no interesse grego por Roma. [...] A assimilação da língua, dos costumes e crenças gregos é indistinguível da criação de uma literatura nacional que, com toda a imitação de modelos alheios, foi imediatamente original, autoconfiante e agressiva.

No decorrer da assimilação da paidéia grega pelos romanos, temos que considerar que a consolidação das letras latinas pode ser observada por meio de aspectos correlatos: o aumento da circulação de livros em Roma, o papel da tradução e a questão da imitação (OLIVA NETO, 1993, p. 7-10). Assim, essa assimilação, para a qual foi decisiva a guerra contra Cartago, de acordo com Momigliano (1990, p. 25), foi um processo rápido e fácil e "os filósofos e retóricos se tornaram parte da forma de vida romana". Além disso, nesse período, houve uma mudança na concepção da transmissão dos saberes, foram criados lugares para reunir acervos de livros e homens cultivados, como a Biblioteca de Alexandria, a Biblioteca e o Mousaion - a morada das musas. Do legado deixado pelo período helenístico, em Roma, destacaram-se três principais escolas filosóficas, a saber: o epicurismo, o ceticismo e o estoicismo.

De acordo com Sabine e Smith o pensamento político do período entre a morte de Aristóteles e o tempo da atividade literária de Cícero - ou seja, quase todo o período helenístico - foi, ao mesmo tempo, importante e obscuro. Obscuro porque não restaram muitos trabalhos da época. Importante porque nesse período ocorreu uma mudança dos grandes ideais sociais e políticos. A visão política de Platão e Aristóteles está atrelada à pólis e sua filosofia política é inteiramente dedicada a ideias e problemas desse tipo de organização política. Mas a pólis deu lugar a grandes impérios, e os ideais políticos de comunidades urbanas centralizadas tiveram de ser reconstituídos para adequar-se à ideia de uma comunidade universal, ao mesmo tempo humana e ampla. Tornou-se necessário pensar em um novo modo de agir que se adequasse a um novo espaço e tempo políticos. Ora a filosofia estoica em Roma era capaz de refletir sobre as ideias dessa nova configuração política.

Assim, independentemente dos grandiosos sistemas tanto de Platão quanto de Aristóteles, os estoicos encontraram preparado seu território. O "uno" deve ser unificado com os "muitos"; a Natureza deve estar em aliança ofensiva e defensiva com o Homem; os homens, como indivíduos, devem estar alinhados com a Humanidade, o universal. Embora os fatores do estoicismo possam ser encontrados no pensamento grego anterior, os catastróficos eventos seculares exigiram sua reorganização. O Helenismo chegou a ter contrastes e exclusões; a originalidade do 
estoicismo está na sua corajosa tentativa de fornecer inclusões, clamor imperativo dadas as circunstâncias da época (WENLEY, 1963, p. 80).

Segundo Ojea (1995, p. 116), desde o término das Guerras Púnicas, houve o surgimento de uma nova força: a potência romana estava disposta a expandir-se por todo o entorno do Mediterrâneo, expansão que foi a base territorial para a criação da pátria unificadora da oikouméne. A nova situação política e social criada pela expansão romana no Mediterrâneo necessitava de uma base teórica adequada. O estoicismo forjou um sistema dogmático de ideias peculiares, com uma direta dependência de uma certa estrutura política e social - a do mundo helenístico da época. Os pensadores do estoicismo médio estavam dispostos a introduzir e adaptar suas teorias éticas e políticas aos postulados dos governantes e soldados com quem entraram em contato (OJEA, 1995, p. 133-134). Foi Panécio de Rodes que, com um contato estreito com a aristocracia romana, principalmente com o Círculo dos Cipiões (ao qual Políbio também pertencia), adaptou o legado estoico aos interesses sociais dominantes (OJEA, 1995, p.135). Desse modo, o estoicismo mostrou-se fértil para a reflexão na república romana.

Em Roma, Panécio introduziu a ideia da reunião dos concidadãos em uma ciuitas, e o cosmopolitismo parece ter cedido espaço para a valorização da pátria e da vida pública. Para Chaui (2010, p.180):

\footnotetext{
Sem afirmar a superioridade da virtude prática sobre a teórica, Panécio deu grande valor à sociabilidade e, por sua relação com Cipião, aderiu ao forte sentimento cívico romano, deixando esmorecer o cosmopolitismo de seus predecessores estoicos. Segundo Bréhier, Panécio viu em Cipião um homem de conduta moral e política admiráveis, e, por sua vez, Cipião nele encontrou um guia moral necessário no momento da ascensão de Roma, com todas as ambições daí decorrentes.
}

Ainda segundo Ojea, para Panécio, apenas o bem moral é o verdadeiro bem para o homem, mas considera que as coisas conformes à natureza são valores reais para alcançar o ideal moral. O valor da vida permite a Panécio mostrar a importância da natureza do homem para a realização da moral. Na racionalidade humana há o impulso de conhecer, viver em sociedade e se submeter à ordem do mundo. São todos impulsos naturais e preciosos para a existência ética. Sua articulação constitui as bases da moralidade e o pressuposto da harmonia do pensamento e da ação sob o respaldo da razão, que são o fim da vida humana, e se firmam em uma conduta conforme as disposições naturais de cada homem. Panécio expõe a importância da natureza de cada homem para a realização efetiva do ideal moral. Ojea 
acrescenta ainda que Panécio, em seu tratado sobre os deveres, integra os homens na circunstância vital, a vida moral do homem na trama de suas determinações externas. Assim:

\begin{abstract}
O espírito humano cria a civilização como uma segunda natureza, no marco de um desígnio finalista do lógos cósmico: o homem formará sua personalidade concreta no contexto de uma família e uma república. As peculiaridades nacionais dos homens não se determinam por uma constelação astrológica, mas por condições geográficas e étnicas, e pelas formas sociais. [...] A conduta se apoia no respeito às coisas conformes a natureza, mas a natureza não é a de um homem abstrato, mas a de um ser concreto e personalizado [...]. (OJEA, 1995, p. 148-149).
\end{abstract}

Cícero é herdeiro do estoicismo de Panécio e pensa a república romana na perspectiva estoica romana, quando não se tratava mais da pólis, nem da Cosmópolis (como para os primeiros estoicos), mas da res publica.

\title{
2.1 O ESTOICISMO CICERONIANO E SUA CONTRIBUIÇÃO PARA PENSAR A REPÚBLICA
}

Radford analisa quais elementos Cícero decidiu acolher de cada historiador, filósofo ou de cada escola ${ }^{2}$ para a sua filosofia política, e aponta quatro elementos estoicos presentes no pensamento político ciceroniano, a saber: primeiro,

\begin{abstract}
que a meta fundamental da vida é viver de acordo com, ou constantemente com, a natureza. Nossa natureza é parte do universo natural, que é racional ou compreensível pela reta razão. A razão pode determinar a lei à qual nossa natureza pode ser conforme. [...] [Segundo], somos naturalmente feitos para viver em comunidades. A justiça, como a lei e a razão, é um assunto da natureza, não uma convenção. [...] [Terceiro], temos que pensar em todo o universo como uma única entidade política. A mesma natureza está em todos os seres humanos, a mesma razão, a mesma divindade vai relacionar todos nós, e a mesma lei natural é relevante para todos nós. [...] [Quarto], os homens sábios devem ser engajados na vida ativa, na política, e devem ser homens políticos (RADFORD, 2002, p. 21).
\end{abstract}

Temos que considerar que a filosofia passou a ser expressa em latim dentro de uma tradição republicana em que os políticos também eram homens sábios. O estoicismo foi eleito para fundamentar a reflexão sobre a res publica. Podemos observar na obra de Cícero - que

\footnotetext{
${ }^{2}$ Radford (2002) identifica que há uma influência indireta de Heródoto por meio da discussão das formas de governo, Tucídides pelas discussões das formas de governo e principalmente pela discussão entre a democracia ateniense e a oligarquia espartana; há uma influência direta de Xenofonte, Ênio e Políbio. Entre os filósofos, Radford identifica influências de: Platão, Aristóteles, os peripatéticos, os estoicos, os acadêmicos e até dos epicuristas, pois foi a primeira escola helenística que Cícero estudou.
} 
opera constantemente com a questão da virtude do ponto de vista prático e teórico, seguindo lições de Panécio - que a virtude dos homens se aproxima da dos deuses na conservação e na fundação das ciuitates. Em Roma, para Cícero, a figura do sábio não estava afastada da vida política, pois escrever era útil à República. Desse modo, elabora-se uma nova figura do homem sábio, educado nas artes liberais, nos costumes romanos ${ }^{3}$ e na vida pública. Assim, a figura do sábio é a figura do sábio político, aquele que participa da vida pública, como Cipião.

Depreendemos da interpretação ciceroniana do estoicismo que a finalidade do homem é viver de acordo com a natureza; o que diferencia o homem dos outros seres é a racionalidade; desse modo, a finalidade do homem é viver de acordo com a razão. Em De Re Publica a ideia de natureza está posta já na explicação do primeiro momento do agrupamento dos homens, dado que os homens se reúnem não por debilidade, mas por uma propensão natural de se congregar, e a razão da qual os homens são dotados pela natureza (que conduz à verdade, ou seja, à vida de acordo com a virtude, que é uma vida de acordo com a natureza) faz a mediação entre a natureza e política, uma vez que os homens têm uma tendência natural para a sociabilidade e, a partir daí, fundam a república. A fundação é uma instituição elaborada pela ação humana, apenas é possível porque os homens são dotados de razão, possuem linguagem e agem deliberadamente. Vejamos os outros elementos que levam o homem a constituir uma república: a ação em conformidade com a razão, a percepção temporal e a linguagem.

De acordo com Goldschmidt (1953, p. 59), a conformidade com a natureza não supõe a realização de uma adequação entre dois termos separados: a natureza não é a norma exterior à qual a ação deve se ajustar; na verdade, há um fim ético em viver em conformidade com a natureza. Estar em conformidade com a natureza é estar em conformidade com a razão. Vejamos a seguinte passagem de De Legibus, I, 56:

[...] sem dúvida é óbvio que o sumo bem consiste ou em viver conforme a natureza, isto é, de uma vida moderada e própria da virtude, ou em seguir a natureza, vivendo de certo modo sob suas leis e sem nada poupar (enquanto seja possível) para realizar o que pede a natureza, o que implica numa vida submetida à virtude e às suas leis (CICERO, 1928, p.360, tradução nossa).

\footnotetext{
${ }^{3} \mathrm{O}$ mos maiorum era um conjunto de costumes e práticas que regulavam a conduta. Tinha três ideias centrais: a fides, a pietas e a uirtus. Essas eram a base para que outros princípios se firmassem, como a gloria, dignitas, grauitas, auctoritas, clemetia, concordia, libertas, honor.
} 
A natureza mostra o lugar do homem e o seu dever. O início do exame dos deveres humanos pode ser visto a partir da separação entre os homens e os animais, feita no De Officiis, I, 11-12:

\begin{abstract}
Mas a diferença mais marcante entre homens e animais é a seguinte: o animal, porque é comandado pelos sentidos e possui uma pequena percepção do passado e do futuro, só é capaz de se adaptar, ele mesmo, aquilo que é do domínio do presente, do agora; porém o homem, porque é dotado de razão, pela qual compreende a relação de causa e consequência e pode, por assim dizer, estabelecer analogias, ligando e associando o presente ao futuro compreende facilmente o curso da vida, fazendo os preparativos necessários para a sua conduta. 12. Essa mesma natureza associa, pela força da razão, homem com homem pelos laços comuns de linguagem e da vida, engendrando nela acima de tudo (se assim posso dizer) um certo desvelo carinhoso pelas suas primícias, que foram primeiro geradas, incitando, além disso, os homens a reunirem-se em assembleias e nelas tomarem parte (CICERONE, 1987, p. 82-84, tradução nossa).
\end{abstract}

As ações do homem devem estar em conformidade com a moral, e isso implica ações virtuosas, logo, políticas - ações e feitos memoráveis - realizadas em um determinado tempo e lugar e com determinada utilidade; trata-se de um agir para ser útil, que vincula a ação à razão. A inclinação natural, ou seja, a inclinação racional leva os homens a agirem de acordo com a uoluntas, que é regida pela racionalidade. Por sua vez, as paixões se opõem à razão. De acordo com Valente as paixões são obstáculos para o homem atingir a felicidade. A razão e a paixão têm regras muito bem definidas. A paixão, diferentemente da razão, tem raízes na opinião, por isso o sábio não pode estar sujeito a elas; é um movimento irracional da alma e contrário à natureza. Os homens guiados pela razão são os sábios, e os guiados pelas paixões são os não sábios ou insensatos. Mas o que nos interessa aqui é a ação dos homens sábios, livres, que desempenham suas tarefas, conservam a virtude, enfim, que agem de acordo com a natureza. A sabedoria é viver, pensar e agir em conformidade com a natureza. Aderir à natureza e estar em conformidade com ela são atitudes próprias do sábio ou o exercício consciente da parte que dirige a alma, ou seja, a razão.

Em De Officiis, I, 50-51, Cícero afirma que o vínculo entre os homens é estabelecido por meio da razão e da linguagem, que associam os homens uns com os outros, reunindo-os numa espécie de sociedade natural. Esse é o aspecto que mais nos afasta da natureza dos animais. Então, o laço que mais une os homens é aquele de uma sociedade na qual todas as coisas que foram criadas pela natureza para usufruto comum dos homens são pertença de toda a comunidade, de tal modo que tudo aquilo que é regulado pelas leis e pelo direito civil possa ser encontrado em conformidade com aquilo que é estabelecido pelas mesmas leis naturais. 
Assim, a tendência natural para constituir uma ciuitas tem a possibilidade de se realizar, uma vez que a natureza associa, por meio da razão, homem com homem pelos laços de linguagem e de vida. Uma vez que, no estoicismo, o universo é racional e o homem é parte dele, a reta razão só pode estar em conformidade com a incitação inicial da natureza.

Lemos no livro III de Sobre a República que a razão, por meio da linguagem, permite a associação - a fundação -, imprime denominações às coisas, faz com que os homens deliberem $^{4}$ e documentem o passado:

3. e com veículos para sua lentidão; como tivesse encontrado os homens proferindo algo incompleto e confuso mediante vozes disformes, as separou e as distinguiu em partes e imprimiu palavras às coisas, como uma espécie de signos; e aos homens, dissociados antes, congregou-os entre si com o vínculo de linguagem. Os sons da voz, que pareciam infinitos, também foram todos, pela mesma mente, identificados e expressos com alguns poucos caracteres inventados, com os quais tiveram tanto colóquios com os ausentes como indicações das vontades e documentos dos feitos passados (CICERO, 1928, p. 184, tradução nossa).

Ou seja, os homens ainda não congregados produzem sons imperfeitos, mas, como este não é o estado no qual os homens devem permanecer, então a razão classifica os sons, dá palavras às coisas e associa entre si os homens por meio do vínculo de linguagem de que ela os dotou. Assim, congregar os homens é uma ação da natureza. O que é instituído o é pela natureza e pela natureza humana em conformidade com a natureza. Ao contrário dos modernos, em Cícero não há ruptura entre a passagem de uma situação de não associação a uma outra de associação, apenas há uma intervenção natural da razão. Os homens realizam sua sociabilidade natural, deliberando, ensinando, aprendendo e documentando os feitos memoráveis. Se os animais, que não possuem linguagem, estão presos no agora, no tempo imediatamente presente, os homens, por meio da articulação da linguagem e da memória, são capazes de organizar o mundo e se relacionar com o tempo. ${ }^{5}$ Assim, estabelece-se um elo da república presente com o passado que dá um sentido para a ação do presente, pela reinterpretação dos exempla. A razão fornecerá a interpretação correta, que guiará a ação para produzir novos feitos memoráveis.

Já na ciuitas que se estabelece o vínculo legal entre os concidadãos, como lemos em $D e$ Re Publica, I, 49, “o que é, pois, a ciuitas senão uma reunião de direitos dos concidadãos?”.

\footnotetext{
${ }^{4}$ Por participação na vida pública podemos entender tanto as discussões, quanto os atos de legislar e deliberar.

${ }^{5}$ A linguagem se apresenta em De Re Publica de três modos: como vínculo que une os homens, como retórica e como narrativa histórica. Esses três modos retratam a política, o vínculo que há entre os homens.
} 
Assim, a ciuitas romana é a totalidade constituída pelos ciues, onde encontramos a lei e esta lei, a lei natural, é a reta razão. De Re Publica, III, XXII, 33:

\begin{abstract}
a lei verdadeira é a reta razão, conforme à natureza, - difusa entre todos, constante, eterna - que chama ao dever ordenando e afasta do mal vetando. Porém, nem ordena nem veta em vão os probos, nem move os ímprobos ordenando ou vetando. Esta lei não pode ser ob-rogada, nem é lícito derrogar alguma parte, nem sua totalidade pode ser ab-rogada. Na verdade, não podemos ser isentos da obediência a essa lei nem pelo senado nem pelo povo, nem devemos procurar outro comentador ou intérprete dela; nem haverá uma lei em Roma, outra em Atenas, outra aqui, outra depois, mas em todas as gentes e em todos os tempos uma lei eterna e imutável. E deus será o único, por assim dizer, mestre e comandante comum a todos - ele é o inventor desta lei, o juiz e quem a propõe. Quem não a cumprir afastar-se-á da sua própria natureza de homem e sofrerá enormes penas, mesmo se escapar do que chamam suplício. (CICERO, 1928, p. 210, tradução nossa).
\end{abstract}

A razão é o vínculo da primeira associação dos homens, e este vínculo se expressa na lei. Assim, os que possuem a mesma lei participam também do mesmo direito, e os que compartilham da mesma lei e do mesmo direito devem se considerar membros de uma mesma associação. O direito não se baseia em convenções, mas na natureza. A convivência baseia-se no princípio de que a humanidade está unida por natural complacência e boa vontade, do mesmo modo que pela comunidade do direito. O direito constitui o vínculo da sociedade humana, e ele nasce de uma só Lei.

Todos os homens vivem sob essa lei natural que não depende das leis e dos costumes da ciuitas, pois eles devem agir de modo que não tenham que se opor às leis universais da natureza. Quando estas são preservadas, a própria índole humana é seguida e, embora se verifique que há naturezas melhores do que outras, tem-se a oportunidade de orientar as realizações segundo a lei natural. Para Cícero é na vida pública, no exercício da virtude, ou seja, na ciuitas que a lei natural melhor se manifesta, pois por intermédio da reta razão é possível guiar e justificar as ações humanas e realizar os feitos políticos. Em De Legibus, I, 18-19, Cícero diz que a lei é a razão suprema da natureza, que ordena o que se deve fazer e proíbe o contrário. Essa razão, uma vez confirmada e desenvolvida pela mente humana, transforma-se em lei escrita ou civil. Logo, a razão determina a lei que exige as boas ações e evita as más. A lei civil deriva da justiça, segundo a qual deve dar a cada um o que lhe cabe. A lei é a força da natureza, é o espírito e a razão do homem dotado de sabedoria prática, é o que confere ao homem o critério do justo e do injusto. Assim, Cícero estabelece uma relação da lei natural com a lei dos homens, mas a lei natural é maior, pois não pode ser contestada, anulada nem derrogada, não pode ser negada pela lei civil. O direito deve ser justo por 
natureza, e ele só possui valor se for justo. Além disso, as leis dos homens são justas apenas se estiverem de acordo com a natureza, pois existe apenas um direito, aquele que estabelece o vínculo entre os homens e que nasce de uma só lei.

Com isso, vejamos o que é a república e a sua relação com a justiça. Pela definição, a coisa pública é a coisa do povo, isto é, o que é do povo é público. Além disso, res publica pode se referir às formas de governo. Mas, no livro III, o conceito de res publica restringe-se às formas de governo justas. Em De Re Publica, I, 39, Cícero define república da seguinte forma:

[XXV] 39. Portanto, - disse Africano -, a república é a coisa do povo, porém o povo não é todos os homens agrupados de qualquer modo, mas congregados em um agrupamento da multidão por seu consenso de justiça e uma reunião de utilidade comum. E a causa primeira para agrupar-se não é tanto a debilidade quanto uma certa naturalidade, por assim dizer, dos homens de se congregarem. De fato, este gênero [humano] não é solitário nem isolado, mas foi gerado de tal forma que nem mesmo na abundância de todas as coisas. (CICERO, 1928, p. 64, tradução nossa).

O povo é definido como um agrupamento da multidão que se reuniu pelo consenso de justiça e pela utilidade comum. O consensus iuris é um consenso quanto ao que é justo, é uma vontade comum de justiça e sem essa não há vida comum. É um assentimento espontâneo dos homens a reunirem-se sob uma regra de justiça que garante a conservação. Há um desejo de se partilhar a norma de justiça. A ideia de justiça e direito natural encontram seus fundamentos na natureza, e a sua manifestação se dá na república. Para entendermos melhor o que chamamos de justiça, podemos opor o ius uniuersum ao ius ciuile. O direito civil é definido para cada povo pelo seu legislador, enquanto que o direito universal é comum a todos os povos e imutável, baseia-se na natureza e não nas convenções humanas. A justiça não existe se não for derivada da natureza. Se a lei natural é o vínculo da sociedade, o ius, que é proveniente da lei, é o laço de coesão da sociedade. Em De Officiis, I, 31, Cícero aponta que os fundamentos da justiça são dois: o primeiro, que ninguém seja lesado, o segundo, que a utilidade comum seja salvaguardada. O que é útil a um deve ser útil a todos, como lemos em De Officiis, III, 27:

se a natureza prescreve que um homem deveria desejar considerar os interesses do seu semelhante, quaisquer que sejam, pela simples razão de ser ele um homem, é necessário, segundo a mesma natureza, que aquilo que é útil para todos de uma certa maneira o deva ser também partilhado em comum. Visto que assim é, somos consequentemente regulados por uma única e mesma lei da natureza. (CICERONE, 1987, p. 334, tradução nossa). 
Desse modo, a utilidade comum nos ajuda a compreender o conceito de justiça. O vínculo social impõe um dever de justiça, um respeito mútuo e colaboração para com os interesses da coletividade; o que dirige a vida social é o consenso de justiça, como pode ser observado em De Re Publica, I, 41.

\subsection{A JUSTIÇA E AS FORMAS DE GOVERNO}

O vínculo entre os homens realiza-se com uma forma política quando a coisa do povo é conduzida pelo discernimento, que dá uma direção ao agrupamento da multidão e deve, em primeiro lugar, refletir a causa que gerou a ciuitas. A república é concedida a um, ou a alguns seletos, ou pode ser assumida pela multidão e por todos. O discernimento conduz o agrupamento, dá à coletividade a possibilidade de longevidade e estabilidade, desde que os preceitos da natureza que geraram a república sejam seguidos. $\mathrm{O}$ homem, ou os homens ou todos os homens, quando têm o comando devem agir sabiamente, de acordo com a natureza e formular leis civis que também estejam em conformidade com as naturais. Assim, quem dirige deve ser aquele ou aqueles homens sábios, educados nas artes liberais e nos costumes romanos.

Devemos salientar que há virtudes que são inerentes a cada forma de governo. Esse parece ser um outro critério usado por Cícero para avaliar as formas simples. Assim: os reis nos cativam pelo amor, os optimates pelo discernimento, e o povo pela liberdade. Os reis devem ser como pais para o povo. Os optimates devem usar o seu discernimento. A liberdade está na vontade do povo. Dessa maneira, temos as seguintes formas puras, e consequentemente justas de governo: o reino, a ciuitas regida pelo arbítrio dos optimates e a ciuitas popular. Para Cícero a vontade de quem rege a república, ou ainda, as virtudes de quem a rege é que lhe dão forma. A falta das virtudes faz com que as formas de governo degenerem, visto que se a república degenera é porque quem a rege é vicioso e ela deixa de se chamar república, pois se torna uma forma injusta. Com isso, as formas de governo se degeneram pelos vícios dos homens e se regeneram pelas suas virtudes. Para Cícero, uma forma de governo pode se degenerar em qualquer outra, sem a necessidade de termos, como em Políbio, a teoria da anaciclose, em que há um ciclo de degeneração e regeneração que segue uma ordem pré-estabelecida. 
A alternativa para fugir do ciclo é um quarto gênero de república, moderado e misto que se origina de partes, ou melhor, das virtudes, dos três gêneros primários. Assim, a degeneração não ocorre no governo misto a não ser quando há grandes vícios provenientes dos homens principais, pois nela as partes se equilibram, como vemos em De Re Publica, I, 69:

\begin{abstract}
Sendo assim, dos três gêneros primários, em minha opinião, o régio é superior, mas superará o próprio régio aquele que for equânime e temperado ${ }^{6}$ pelas três primeiras formas de república. De fato, apraz que haja na república algum elemento notável e real, que haja algo concedido e outorgado à autoridade dos principais e que haja alguns assuntos reservados ao juízo e à vontade da multidão. Esta constituição tem, primeiramente, uma grande igualdade, por assim dizer, da qual, dificilmente, os homens livres podem carecer por muito tempo. (CICERO, 1928, p. 104, tradução nossa).
\end{abstract}

O equilíbrio das virtudes e das partes existentes no governo misto romano é o que garante a longevidade de Roma, pois a conduz à concórdia. Ademais é a justiça uma virtude, presente nos homens que buscam a utilidade comum, que garante a manutenção das formas puras de governo ou mesmo do governo misto. E seria no governo misto que a justiça atenderia de uma única vez e de forma mais ampla a todas as partes da sociedade.

\title{
REFERÊNCIAS
}

ABBAGNANO, N. Dicionário de filosofia. 4.ed.bras. São Paulo: Martins Fontes, 2000.

BENVENISTE. Mélanges offerts à Claude Lévi-Strauss à l'occasion de son $\mathbf{6 0}^{\circ}$

anniversaire. Jean Pouillon e Pierre Maranda. La Haya, Mouton \& Co., 1970, pp. 489-496.

BRUNT, P. A. The fall of the roman republic and related essays. New York, Oxford University Press, 1988.

CHAUI, M. de Souza. Introdução à filosofia: as escolas helenísticas. São Paulo, Companhia das Letras, 2010. Vol.II.

CICERO. De oratore. Book III. De fato. Paradoxa stoicorum. De partitione oratoria (with an English translation by H. Rackham). Cambridge, MA: Harvard University Press, 1997.

CICERO. De oratore. Books I and II (with an English translation by E. W. Sutton.

Completed with an introduction by H. Rackham). Cambridge, MA: Harvard University Press, 1942.

\footnotetext{
${ }^{6}$ Aequatum et temperatum: Cícero usa duas formas parecidas em I, 45, moderatum et permixtum.
} 
CICERO. De re publica. De legibus. With a English translation by Clinton Walker Keyes. Cambridge, MA, Harvard University Press, 1928.

CICERO. I doveri (Saggio introduttivo e note di Emanuele Narducci. Traduzione di Anna Resta Barrile). Milano, BUR, 1987.

GELAIN, Itamar L.(org). Uma introdução à filosofia do direito. Ijuí:Unijuí, 2015.

GOLDSCHMIDT, V. Le système stoïcien et l’idée de temps. Paris: Librairie Philosophique J. Vrin, 1953.

KIRK, G. S; RAVEN, J. E.; SCHOFIELD, M. Os filósofos pré-socráticos. 4. ed. Lisboa: Fundação Calouste Gulenkian, 1994.

MASCARO, Alysson Leandro. Filosofia do direito. 5. ed. São Paulo: Gen/Atlas, 2016.

MOMIGLIANO, A. Os limites da helenização. Rio de Janeiro, Jorge Zahar Editor Ltda., 1990.

OJEA, G. P. Ideologia e historia. El fenómeno estoico en la sociedad Antigua. Madrid, Siglo veintiuno de España Editores, sa., 1995.

OLIVA NETO, J. A. O livro de catulo: poemas traduzidos. Dissertação [mestrado] apresentada à FFLCH, USP. São Paulo, 1993.

PEREIRA FILHO, Gerson. In: GELAIN, Itamar L. (org). Uma introdução à filosofia do direito. Ijuí:Unijuí, 2015.

PLATON. Les lois. Oeuvres complètes. Diès, A. (Ed.). Paris: Les Belles Lettres, 1956.

POLYBIUS. The histories. (with an English translation by W. R. Paton). vol 1. Londres, William Heinemann Ltd., 1960.

RADFORD, R. T. Cicero: a Study in the origins of republican philosophy. Amsterdam, Editions Rodopi B.V., 2002.

SOUZA, F.C. Os pré-Socráticos. Fragmentos, Doxografia e Comentários. (Os Pensadores). São Paulo: Abril Cultural. 1985.

TARN, W.; GRIFFITH, G. T. La civilización helenística. Mexico, Fondo De Cultura Economica, 1982.

VOGT, K. M. Law, reason and the cosmic city: political philosophy in the early Stoa. New York, Oxford University Press, 2008.

WENLEY, R.M. Stoicism and its influence. New York, Cooper Square Publishers, 1963. 